\title{
FORECASTING POTENTIAL RISKS OF LEAKAGE ON GAS PIPELINES
}

\section{Volodymyr Grudz; Vasyl Zapukhlyak; Volodymyr Grudz (junior); Lubomyr Poberezhnyi; Nataliya Drin; Roman Stasyuk}

\author{
Ivano-Frankivsk National Technical University of Oil and Gas, \\ Ivano-Frankivsk, Ukraine
}

\begin{abstract}
Summary. Long-term operation of the gas pipelines causes the metal aging because of the corrosion processes and accidents, which results in gas leak of pipelines. It is improvident from both economic and ecological points of view, as the gas leak can cause the gas hazard of great territory and in some cases formation of the gas-air mixture and exposure, as the result of which there happen to be sufficient economic losses and danger for human lives. In the paper statistic analysis of accidents at the pipelines has been carried out, which will make possible to estimate the level of influence of different factors on the probability of arising the leaks and their sizes. It was revealed, that under the pipelines corrosion damage the insufficient leaks are the most possible, and in accidents caused by the influence of the external forces sufficient leaks are the most probable. The appearance of the gas leak from the gas-pipe is generally known to be caused by the non-stationary process according to the nature of which the leak amount can be estimated. If the gas-pipe before the appearance of leak has been operating in the non-stationary regime, the appearance of leak will result in disturbing in the nonstationary process. To reveal the leak the pumping over flow is modeled in the place of leak basing on the determination approach as well as its duration relatively the sizes of the leak. The available determination mathematic models for revealing the leaks need information on the amount of losses of the leak and geometric sizes of the accident hole, which is not available in the moment of accident. That is why the model, which makes possible to predict the amount of leak in whole in all types of failures and some reasons of failures basing on the statistic data have been developed in the paper. It makes possible to choose the most efficient solutions for the diagnostics and preventing the leaks in the main pipelines.
\end{abstract}

Key words: gas pipelines, diagnostics, failure, leak, statistics, distribution of values.

Statement of the problem. Recently the problem of gas leakage diagnostics has become pressing. On the one hand it is caused by the gas transportation pipelines aging and as a result great probability of flows initiation, caused by the corrosion processes, on the other, it is the result of non-approvable gas picking out.

Analysis of the results of investigation. Many papers are devoted to the investigations of the non-stationary processes and propose mathematic models of non-stationary regimes, methods of their realization, analysis of technological restrictions [1-8]. The idea of the leaks diagnostics of the gas and oil pipelines is based on the investigation of changes in the amplitude frequency characteristics during picking out from the pipeline.

The diagnostics model of the gas transportation system must connect the main parameters of gas pumping with the diagnostics characteristics. As to the branching gas system this model must include the information on the characteristics and operation regimes of the gas picking out.

The main requirements to the diagnostics models are those their quick-acting and adequacy. The first is that of the model realization being rather short in order to make decision very quickly according to the results of diagnostics. The second must guarantee the reliability 
of the obtained results. To meet the requirements totally it is impossible, as they are contradicting each other.

The Objective. The leak diagnostics, basing on the determination mathematic models, needs information on the leak losses amount and the sizes of the accident hole, which is not available at the moment of the leak initiation. That is why it is necessary to develop the model, which will make possible to predict the amount of leak in whole in all cases of failure, as well as other reasons of failures basing on the statistic data.

Statement of the task. The statistics on the accidents at pipelines makes possible to make quantity estimation of the probability of the leaks arising at the pipelines, as well as to determine their sizes [9]. Besides, the analysis of similar situations gives the possibility to determine the degree of different factors effect on the probability of the leaks appearance and their sizes. During the statistic analysis there were identified five reasons of leaks:

- the metal fracture caused both by the propagation of the available damages in the original material and those appeared during manufacturing of pipes and pipeline structures. Such damages can be those of welding defect, stratification, etc;

- corrosion, which results in the pipelines wall fracture during their operation;

- the operator's errors during the operation and maintenance of the pipelines;

- the influence of the external forces, e. g. ditching machines;

- the influence of environment. These can be such phenomena as soil shrinkage, soil erosion because of heavy raining, etc.

The processing of statistics data made possible to estimate the frequency of the leaks arising according to every of these reasons separately. Lately the main reasons are those of metal damages and corrosion. The probability of the leaks arising because of these reasons is in 10 times higher than that of leaks caused by the influence of the external forces.

This conclusion contradicts the materials published earlier, according to which the most probable reason of the pipelines fracture is that caused by the influence of the external forces. But in the mid-70s the influence of the external forces was the overwhelming reason of the pipelines fracture. But soon the most reasons of accidents were those of the material fracture and corrosion.

The data testifies the trend of gradual increase of total number of leaks during last years, although these changes are not so sufficient as the number of leaks according to special categories of the accident reasons.

According to the data for the last 5 years of the pipelines operation the probability of the leaks caused by special categories of reasons is presented on the Table 1 .

Table 1

Probability of leaks arising

\begin{tabular}{|l|c|}
\hline \multicolumn{1}{|c|}{ Categories of leak arising reasons } & Value, $\%$ \\
\hline Material fracture & 14,7 \\
\hline Corrosion & 8,8 \\
\hline Operator's error & 8,8 \\
\hline External forces influence & 2,0 \\
\hline Environment influence & 2,0 \\
\hline
\end{tabular}

One of the characteristic features of the pipeline transportation is the probability to loose great amount of product while the leaks arising. There are two approaches to the estimation of the possible leaks amount. In the first case the amount of possible leaks is estimated basing on the statistical data of the last period of time. In the second case the determination approaches is used, when the flow of pumping over in the place of leak is modeled and its duration relatively 
the leak sizes. While analyzing the first approach has been chosen, which is based on the statics of the last years.

To determine the dependence of the probability of different sizes leaks arising on the listed above reasons, all leaks were categorized in three types: small $\left(0 \ldots 70\right.$ ths. $\mathrm{m}^{3} /$ year $)$, medium-size (70...300ths. $\mathrm{m}^{3} /$ year) and great (over 300ths. $\mathrm{m}^{3} /$ year)

The most probable are small leaks under corrosion damage. It is explained by the fact that, for example, the pit corrosion is accompanied by the appearance of relatively small pits in the pipeline walls and it limits the leak sizes. During accidents caused by the external forces large leaks are the most probable.

Although the economic, ecological and social consequences of leaks at pipeline transportation are specified first of all by the sizes of these leaks, it doesn't mean that just these reasons are to be taken into account, which result in the greatest leaks arising. The frequency of their happening is of importance as well, irrespective of this or that reason.

Thus, if the frequency of their arising is taken into account, the probability of great leaks arising because of the material fracture appears to exceed in two times the probability of similar leaks caused by all other reasons together. The next place in the rank of probability of great leaks arising are those caused by the external forces and the operator's errors.

The sufficient reason of great leaks caused by the materials fracture is that of crack-like fractures in the material, which can propagate for beyond its initial borders being followed by the substantial pipelines damages.

Analysis of this data makes possible to develop the method for predicting the leaks amount at the pipelines. In its turn the prediction of the leaks amount basing on the presented statistic information allows to specify the directions of development of the modeling methods and identify the leaks, as well as the range of these methods application. It is caused by the fact, that «small» and «great» leaks must be identified using different mathematic approaches, control devices, etc.

The first group of the losses components is minimum, when the pipeline reliability is raised, that is, when the efficiency of its operation is raised. But ecological losses can be at the previous level. The raising of the power supply reliability of the pumping equipment, which is often the reason of transporting stoppage, sufficiently increases the reliability characteristics of the pipeline, but the possible ecological losses are sufficiently less. That is why while solving the problem of raising the pipelines reliability it is worth to identify two aspects: operational and ecological.

The operation reliability characteristics are the parameters of the failure flow, meancycles-to-failure and that of between sequence failures. To estimate the ecological reliability it is worth using the parameters, which make possible to predict the amounts of single accident leaks, and total leaks (during certain period of time) being specified by the conditions of operation. The latter causes the need to develop the methods of prediction the amount of leak while the pipelines operating.

The main investigation ideas. One of the possible approaches to the solving of the problem in question is the prediction method for leaks amount basing on the statistical data [10, 11]. The mean value of the leak amount $V$ and average-quadratic error for the series being analyzed is equal to, correspondingly:

$$
V=\sum_{i=1}^{k} V_{c i} P_{i}, \quad \sigma=\sqrt{\sum_{i=1}^{k}\left(V_{c i}-V\right)^{2} P_{i}},
$$

where $k$-is the number of intervals in the variation series; $V_{c i}-$ is the value of the $i$-th interval mid; $P_{i}-$ is the empiric probability of the $i$-th interval. The variation coefficient being the relative (dimensionless) characteristic of the leaks amount scattering is equal to 


$$
\gamma=\frac{\sigma}{V}
$$

According to the variation coefficient let us hypothesize, that the analyzed statistical data is subject of the Weibull law and the distribution function $F(V)$ looks like:

$$
F(V)=1-b \exp \left[-\left(\frac{V}{a}\right)^{b}\right]
$$

where $a$-is the scale parameter, $b$ - is the shape parameter.

Let us check the hypothesis according to the Pirson's criterion $\chi^{2}$, which is the sum of error square of empiric and theoretical frequencies in every interval of the variational series of the statistical information. The theoretical frequency in the $i$-th interval $m_{\gamma i}$ can be found:

$$
m_{\gamma i}=N\left[F\left(V_{i k}\right)-F\left(V_{i p}\right)\right]
$$

where $N$ - is the number of statistical data; $F\left(V_{i k}\right), F\left(V_{i p}\right)$ - are the values of integral functions at the beginning and at the end of the $i$-th interval correspondingly.

\begin{tabular}{|c|c|c|c|c|c|c|c|}
\hline \multirow[b]{2}{*}{$\begin{array}{l}\text { Interval } \\
\text { number }\end{array}$} & \multirow[b]{2}{*}{$\begin{array}{c}\text { Grouping } \\
\text { interval, ths. } \\
\mathrm{m}^{3} / \text { year }\end{array}$} & \multirow[b]{2}{*}{$\begin{array}{c}\text { Midinterval } \\
\qquad V_{c i}\end{array}$} & \multirow[b]{2}{*}{$\begin{array}{l}\text { Empiric } \\
\text { frequency }\end{array}$} & \multirow[b]{2}{*}{$\begin{array}{c}\text { Empiric } \\
\text { probability } \\
P_{i}\end{array}$} & \multicolumn{3}{|c|}{ Calculation values } \\
\hline & & & & & $\begin{array}{c}\text { Theoretic } \\
\text { frequency } \\
m_{\gamma i}\end{array}$ & $m_{i}-m_{\gamma i}$ & $\chi^{2}$ \\
\hline 1 & до 50 & 25 & 76 & 0,500 & 73 & 3,0 & 0,123 \\
\hline 2 & $50 \ldots 100$ & 75 & 20 & 0,132 & 18,2 & 1,8 & 0,178 \\
\hline 3 & $100 \ldots 150$ & 125 & 11 & 0,072 & 10,7 & 0,3 & 0,008 \\
\hline 4 & $150 \ldots 200$ & 175 & 8 & 0,053 & 9,1 & $-1,1$ & 0,133 \\
\hline 5 & $200 \ldots 250$ & 225 & 6 & 0,039 & 5,3 & 0,7 & 0,093 \\
\hline 6 & $250 \ldots 300$ & 275 & 5 & 10,033 & 4,4 & 0,6 & 0,082 \\
\hline 7 & $300 \ldots 400$ & 350 & 8 & 0,053 & 7,0 & 1,0 & 0,143 \\
\hline 8 & $400 \ldots 600$ & 500 & 7 & $0 ; 046$ & 8,1 & $-1,1$ & 0,149 \\
\hline 9 & $600 \ldots 1000$ & 800 & 5 & 0,033 & 7,7 & $-2,7$ & 0,1947 \\
\hline 10 & 1000 & 3000 & 6 & 0,039 & 8,5 & $-2,5$ & 0,735 \\
\hline
\end{tabular}

Table 2

Variational series of the leaks amount

Presented mathematic model of the leak amounts distribution was built basing on the statistic data according to all types of failures. Besides, as the operation experience shows, the specific value of definite reasons of failure differs greatly. The corresponding amounts of leaks are different as well. 
In order to improve the prediction of leaks amount and increase the reliability of the pipelines operation there is a need of differential registration of the influence of the failures reasons on the leaks amount.

The most part of failures is caused by the materials fracture. To identify the mathematic dependence of the leak value distribution, caused by the materials fracture, the interval variation series has been built (Table 3).

Table 3

Interval variational series of the leak values caused by the material fracture

\begin{tabular}{|c|c|c|c|c|c|c|c|}
\hline \multirow[b]{2}{*}{ 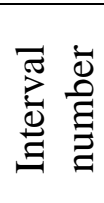 } & \multirow{2}{*}{$\begin{array}{c}\text { Grouping } \\
\text { interval } \\
\tau \\
\text { ths. } \mathrm{m}^{3} / \text { year }\end{array}$} & \multirow[b]{2}{*}{$\begin{array}{l}\text { Midinterval } \\
\qquad V_{c i}\end{array}$} & \multirow[b]{2}{*}{ 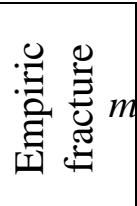 } & \multirow{2}{*}{$\begin{array}{c}\text { Empiric } \\
\text { probability } \\
P_{i}\end{array}$} & \multicolumn{3}{|c|}{ Calculation values } \\
\hline & & & & & $\begin{array}{l}\text { Theoretical } \\
\text { frequency } m_{\gamma i}\end{array}$ & $m_{i}-m_{\gamma_{i}}$ & $\chi^{2}$ \\
\hline 1 & $0 \ldots .50$ & 25 & 25 & 0,4 & 23,3 & 1,7 & 0,124 \\
\hline 2 & $50 \ldots 100$ & 75 & 10 & 0,16 & 8,3 & 1,7 & 0,348 \\
\hline 3 & $100 \ldots 200$ & 150 & 9 & 0,14 & 9,5 & $-0,5$ & 0,026 \\
\hline 4 & $200 \ldots 300$ & 250 & 7 & 0,11 & 5,7 & 1,3 & 0,297 \\
\hline 5 & $300 \ldots 500$ & 400 & 5 & 0,08 & 6,4 & $-1,4$ & 0,306 \\
\hline 6 & $>500$ & 1550 & 7 & 0,11 & 9,8 & $-2,8$ & 0,80 \\
\hline
\end{tabular}

Basing on the probability-statistical method of investigations, carried out basing on the presented method, the parameters of empiric and theoretical distributions have been found, the values of which are presented on Table 4.

Table 4

Empiric and theoretical distribution parameters

\begin{tabular}{|l|c|c|c|}
\hline \multirow{2}{*}{ Numerical characteristics } & \multicolumn{3}{c|}{ Number values of failure } \\
\cline { 2 - 4 } & $\begin{array}{c}\text { Material } \\
\text { fracture }\end{array}$ & $\begin{array}{c}\text { Metal } \\
\text { corrosion }\end{array}$ & $\begin{array}{c}\text { All types } \\
\text { of failures }\end{array}$ \\
\hline Average leak amount & 237 & 6,4 & 243,5 \\
\hline Midquadratic error & 462 & 5,5 & 582,3 \\
\hline Variation coefficient & 2,39 & 6,8 & 2,39 \\
\hline $\begin{array}{l}\text { The Weibull theoretical distribution parameters: } \\
\text { Parameter } B\end{array}$ & 0,6 & 1,2 & 0,5 \\
\hline Parameter $a$ & 180 & 6,8 & 120 \\
\hline
\end{tabular}

The testing of the hypothesis on the Weibull distribution law testified the possibility of its application for predicting the leak amounts, which differ in different failures caused by the materials fracture and corrosion.

Conclusions. The proposed mathematic models make possible to predict the leaks amount of the product in whole according to all types of failure, as well as some special reasons of failures. Moreover, it makes possible to choose the most efficient solutions for the diagnostics and to prevent the leaks at the main pipelines. 


\section{Refferencies}

1. Grudz V. Ya., Tymkiv D. F., Yakovlev E. Y. Obcluzhyvanye hazotrancportnыkh cyctem. K.: UMKVO, $1991.159 \mathrm{p}$.

2. Grudz V. Ya., Tymkiv D. F., Mykhalkiv V. B. ta in. Obsluhovuvannia i remont hazoprovodiv. IvanoFrankivsk: Lileia-NV, 2009. 711 p.

3. Grudz V. Ya., Kovalko M. P., Mykhalkiv V. B. ta in. Truboprovidnyi transport hazu. K.: ArenaEKO, 2002. $600 \mathrm{p}$.

4. Serediuk M. D., Malyk V. Ya., Bolonnyi V. T. Proektuvannia ta ekspluatatsiia system hazopostachannia naselenykh punktiv: navch. posibnyk. Ivano-Frankivsk: Fakel, 2003. 140 p.

5. Stasiuk R. B., Zapukhliak V. B., Belei O. I., Pyrih T. Iu., Tutko T. F. Vplyv nerivnomirnosti hazospozhyvannia na nestatsionarnyi protses, vyklykanyi poiavoiu vytoku hazu $\mathrm{z}$ hazoprovodu. Naftohazova haluz Ukrainy. 2018. № 4. P. 22-26.

6. Grudz V. Ya., Grudz Ya. V. (junior), Drin N. Ya., Stasiuk R. B. The research of gas leak from the. Journal of hydrocarbon power engineering. 2014. № 2. P. 103-107.

7. Grudz V. Ya., Grudz V. Ya. (junior), Zapukhlyak V. B., Kyzymyshyn Ya. V. Non-stationary processes in the gas transmission systems at compressor stations shut-down. Journal of hydrocarbon power engineering. 2018. № 1 (5). P. 22-28.

8. Olijnyk A., Shtaier L., Belei O., Stasyuk R., Yasinetska I. Modeling of the filtration processes in a rectangular area soils using the darcy. Eastern-European Journal of Enterprise Technologies. Volume 6/10 (90). 2017. P. 24-30. https://doi.org/10.15587/1729-4061.2017.116114

9. Honcharuk M. I. Analiz prychyn vtrat pryrodnoho hazu. Naftova i hazova promyslovist. 2003. № 1. P. 51-53.

10. Hukhman A. A. Vvedenye v teoryiu podobyia. M.: Vychshaia shkola, 1973. 254 p.

11. New concept single signature vibration monitoring through the lifetimes of an engine. Aireraft Engeneering. 1979. 51. 3. P. 21-22. https://doi.org/10.1108/eb035521

\section{Список використаної літератури}

1. Грудз В. Я., Тымкив Д. Ф., Яковлев Е. И. Обслуживание газотранспортных систем. К.: УМКВО, $1991.159 \mathrm{c}$.

2. Грудз В. Я., Тимків Д. Ф., Михалків В. Б. та ін. Обслуговування і ремонт газопроводів. ІваноФранківськ: Лілея-НВ, 2009. 711 с.

3. Грудз В. Я., Ковалко М. П., Михалків В. Б. та ін. Трубопровідний транспорт газу. К.: АренаЕКО, $2002.600 \mathrm{c}$.

4. Середюк М. Д., Малик В. Я., Болонний В. Т. Проектування та експлуатація систем газопостачання населених пунктів: навч. посібник. Івано-Франківськ: Факел, 2003. 140 с.

5. Стасюк Р. Б., Запухляк В. Б., Белей О. І., Пиріг Т. Ю., Тутко Т. Ф. Вплив нерівномірності газоспоживання на нестаціонарний процес, викликаний появою витоку газу з газопроводу. Нафтогазова галузь України. 2018. № 4. С. 22-26.

6. Grudz V. Ya., Grudz Ya. V. (junior), Drin N. Ya., Stasiuk R. B. The research of gas leak from the. Journal of hydrocarbon power engineering. 2014. № 2. P. 103-107.

7. Grudz V. Ya., Grudz V. Ya. (junior), Zapukhlyak V. B., Kyzymyshyn Ya. V. Non-stationary processes in the gas transmission systems at compressor stations shut-down. Journal of hydrocarbon power engineering. 2018. № 1 (5). P. 22-28.

8. Olijnyk A., Shtaier L., Belei O., Stasyuk R., Yasinetska I. Modeling of the filtration processes in a rectangular area soils using the darcy. Eastern-European Journal of Enterprise Technologies. Volume 6/10 (90). 2017. P. 24-30. https://doi.org/10.15587/1729-4061.2017.116114

9. Гончарук М. І. Аналіз причин втрат природного газу. Нафтова і газова промисловість. 2003. № 1. C. 51-53.

10. Гухман А. А. Введение в теорию подобия. М.: Высшая школа, 1973. 254 с.

11. New concept single signature vibration monitoring through the lifetimes of an engine. Aireraft Engeneering. 1979. 51. 3. P. 21-22. https://doi.org/10.1108/eb035521 
УДК 622.691.48

\title{
ПРОГНОЗУВАННЯ ПОТЕНЦІЙНИХ РИЗИКІВ ВИНИКНЕННЯ ВИТОКІВ НА ГАЗОПРОВОДАХ
}

\author{
Володимир Грудз; Василь Запухляк; Володимир Грудз (молодший); \\ Любомир Побережний; Наталія Дрінь; Роман Стасюк
}

\author{
Івано-Франківський національний технічний університет нафти і газу, \\ Івано-Франківськ, Україна
}

\begin{abstract}
Резюме. Значні терміни експлуатації газопроводів викликають старіння металу внаслідок корозійних процесів та аварій, щуо призводить до появи витоків з трубопроводів. Така ситуація $\epsilon$ неприпустимою з економічної та екологічної точок зору, оскільки витік газу може призвести до загазованості значної території, а в деяких випадках - до утворення газоповітряної суміші й вибуху, в результаті якого виникають суттєві економічні збитки та небезпека для людського життя. Проведено статистичний аналіз аварійних ситуацій на трубопроводах, який дозволяє оцінити ступінь впливу різноманітних факторів на ймовірність виникнення витоків і їх розміри. Встановлено, щуо при корозійних пошкодженнях трубопроводів найбільш ймовірні малі витоки, а при аваріях, зумовлених впливом зовнішніх сил, найвірогіднімі великі витоки. Загальновідомо, що поява витоку газу з газопроводу викликає нестаціонарний процес, за характером протікання якого можна оцінити величину витоку. Якщо газопровід перед появою витоку працював у нестаціонарному режимі, то поява витоку внесе збурення в протікання нестаціонарного прочесу. Для виявлення витоку, на основі детермінованого підходу, моделюється потік перекачування в місиі витоку і його тривалість стосовно конкретних розмірів витоку. Існуючі детерміновані математичні моделі для виявлення витоків потребують інформачії про величину витрати витоку та геометричні розміри аварійного отвору, яка на момент часу виникнення витоку відсутня. Тому в статті розроблено модель, яка дозволяє прогнозувати обсяги витоку продукту в иілому по всіх видах відмов, а також по окремих причинах відмов на основі статистичних даних. Це дає можливість вибрати найефективніші рішення для діагностики та запобігання витоків у магістральних трубопроводах.
\end{abstract}

Ключові слова: газопровід, діагностування, дефекти, витоки, статистика, розподіл величин.

https://doi.org/10.33108/visnyk_tntu2019.04.032

Отримано 14.01.2020 